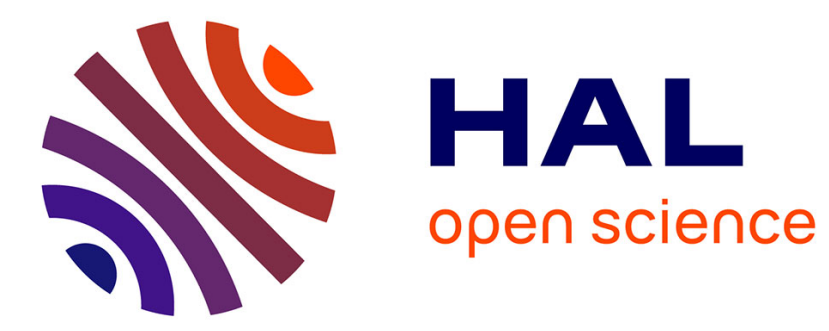

\title{
The Role of Trust in the Prioritization of Channel Choices
}

\author{
Kai-Jo Fu, Chung-Pin Lee
}

\section{To cite this version:}

Kai-Jo Fu, Chung-Pin Lee. The Role of Trust in the Prioritization of Channel Choices. 13th International Conference on Electronic Government (EGOV), Sep 2014, Dublin, Ireland. pp.96-105, 10.1007/978-3-662-44426-9_8. hal-01401729

\section{HAL Id: hal-01401729 \\ https://hal.inria.fr/hal-01401729}

Submitted on 23 Nov 2016

HAL is a multi-disciplinary open access archive for the deposit and dissemination of scientific research documents, whether they are published or not. The documents may come from teaching and research institutions in France or abroad, or from public or private research centers.
L'archive ouverte pluridisciplinaire HAL, est destinée au dépôt et à la diffusion de documents scientifiques de niveau recherche, publiés ou non, émanant des établissements d'enseignement et de recherche français ou étrangers, des laboratoires publics ou privés. 


\title{
The Role of Trust in the Prioritization of Channel Choices
}

\author{
Kai-Jo Fu and Chung-Pin Lee \\ Shanghai University of Finance and Economics, China \\ kaijofu@gmail.com \\ Tamkang University, Taiwan \\ chungpin@mail.tku.edu.tw
}

\begin{abstract}
The role of trust is a significant element in the digital channel. While most studies have examined how the idea of trust has affected users' behaviors and developed integrative models of e-government, little attention has been paid to its critical role as a factor affecting citizens' preference toward certain service channels. There is no systematic investigation to compare different types of channel choices by differentiating between primary public service deliveries such as government information, application and transaction, and eparticipation. Therefore, the purpose of this study is to explore how to perceive the role of trust as a possible determinant of service choice, in terms of different types of government services. Using survey data collected in Taiwan 2011, this study utilized a multinominal logistic analysis to examine the proposed models. The findings suggest that the different types of channel choices can be influenced by certain critical elements such as, political trust, trust in the Internet, and risk concern.
\end{abstract}

Keywords: e-governance, trust, citizen preference, channel choice

\section{Introduction}

The promise of e-government can expand the scope for citizens' interaction with governments and reduce the cost of democratic participation. As a result, many countries have swiftly embraced the Internet as a means to improve the quality of public service delivery and to contribute to the legitimacy of governance [7], [18]. However, even though growing investment in e-government appears have made it the perfect channel choice for the public, research has found that citizens are not fully exploiting the use of Internet services [14], [16]. Recent studies reveal that one of the most significant missing links in the implementation of e-government is the understanding of the role trust plays in the digital channel [5], [19]. A great deal of research has demonstrated that trust is an influential variable which affects citizens' willingness to use 
e-government services [2], [6], [13]. While most studies have examined how the idea of trust affects users' behaviors and develops integrative models of e-government [4, 5], [12], [17], little attention has been paid to its role as a critical factor which affects citizens' preference toward service channels.

Despite the emphasis placed on significant facets of e-government, research has found that most of these Web contacts have been limited to information searching and retrieval, instead of employing citizeninitiated contacts [15], [18]. When compared with other service channel choices, recent studies reveal that the use of traditional channels (e.g., telephone and face-to-face) still remains higher than the use of Internet services [9], [14]. The results demonstrate that channels have different characteristics, which make them useful for purposes with different requirements. However, there is no systematic investigation to compare different types of channel choices by their delivery of different primary public services such as, information, application and transaction, and eparticipation. In other words, there is a need to develop fundamental knowledge to uncover the determinants of channel choices.

Therefore, the aim of this study is to explore the role of trust as a possible determinant of service choice, which differentiates and prioritizes different types of e-government functions. First, we review the literature in relation to trust and various intentions for the use of egovernment services across different lines of disciplines. Next, this study proposes the research model and hypotheses in terms of the theoretical foundation. We test three types of public service delivery, including, knowing government information, government service application, and E-voting. This study utilizes a multinominal logistic analysis, in the analysis of a large sample collected in Taiwan, to examine these models. Finally, the results and the implications of these findings are discussed.

\section{A Framework of Trust in E-government}

\subsection{The concept of trust}

As more and more concerns are uncovered by the current research on egovernment, researchers and practitioners have emphasized how the idea of trust affects e-government adoption and the role of trust in electronic environments [4, 5], [20]. Drawing from e-commerce literature, 
most e-government researchers point to two essential factors that can affect citizens' adoption of digital services, trust in e-service vendor and trust in service delivery technology. In other words, we can find that there are two types of trust which are often discussed in the literature of e-government, they are trust in technology and trust in organization [6], [17].

Recently, researchers have integrated technology acceptance model (TAM) and Diffusion of Innovation (DOI) into e-governance study. These models are applied in a variety of e-government adoption research [6], [10]. In particular, the concept of trust in some studies stresses the trust in e-government, which is indicated as the successful carrying out of on-line transactions and the establishment of a reliable system [1].

From the perspective of information system study, introducing a new technology can mean an increase in benefits gained, as well as an increase in risks, for the end-user. Trust in Internet and technology can affect citizens' willingness to use e-government services. Moreover, from the perspective of political science and public administration, scholars argue that citizens have a higher probability of accepting and supporting public policies, and higher willingness in using egovernment services, if they trust in governments. Since people have multiple channels at their disposal to interact with governmental agencies, the purpose of our study is to identify what role of trust plays in the prioritization of channel choices. Therefore, we propose three fundamental types of trust production mechanisms in e-governance, including government-based trust, technology-based trust, and egovernment-based trust. In addition, perceived risks and privacy concerns are expected to hinder the use of e-government services [19].

\subsection{Satisfaction with e-government services}

Cyber consumer satisfaction represents a predominant concept in ecommerce success [8] and e-loyalty [3]. The contentment of the customer, with respect to his/her prior purchasing experience, can affect his/her psychological state and potential to develop a close relationship with the e-commerce firm. Likewise, prior studies have emphasized that citizens' satisfaction with e-government services can, in turn, increase public trust in government [11], [20]. Apparently, satisfaction with e-government services can be applied in predicting citizens' pref- 
erences toward service channels, where the interaction could be in favor of the e-government service. On the contrary, dissatisfied citizens are more likely to resist attempts to use e-government services and search for alternatives.

\subsection{Models}

Based on the aforementioned literature, we propose the following model involving factors anticipated to influence citizens' preference toward channel choice.

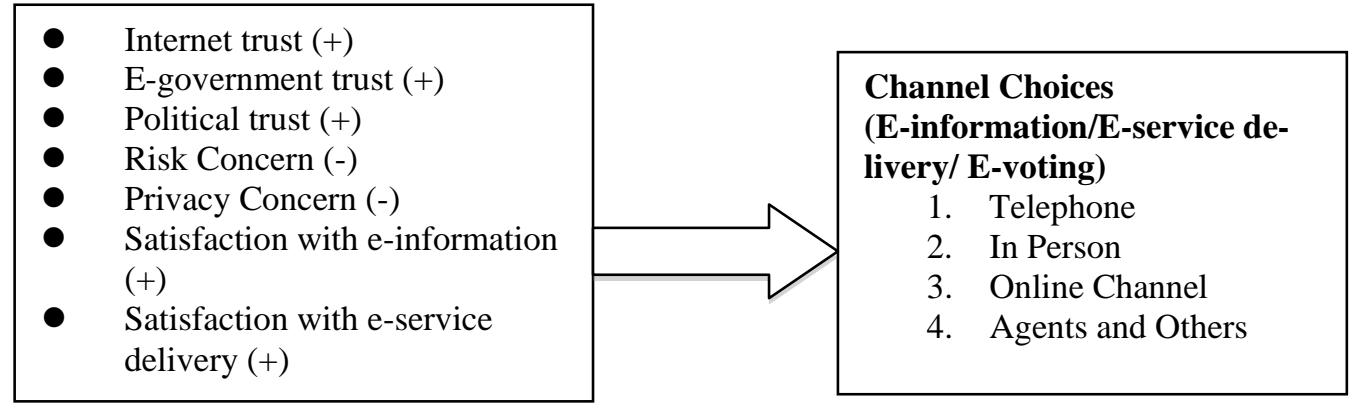

Fig. 1. Factors Anticipated to Influence Citizens' Preference toward Channel Choices

\section{$3 \quad$ Research Method}

\subsection{Case background}

In recent years, reforming government has become a global trend. In line with these developments, Taiwan has built four phases to implement a comprehensive program of e-government. The major goals of egovernment are to simplify the administrative process, improve government efficiency, and increase citizens' satisfaction. In order to accomplish the e-government plan, the central government has raised egovernment spending to expand the scope of the program implementation. According to the assessment of the World Economic Forum Readiness Index in 2013, the e-government in Taiwan has not only stayed ahead of the world average, but also demonstrates high readiness and usage around the world ${ }^{1}$.

\footnotetext{
${ }^{1}$ http://www.weforum.org/reports/global-information-technology-report-2013
} 


\subsection{Data and methodologies}

Data for this study are derived from a random sampling telephone interview survey conducted from August 30 to September 6 in 2011 in Taiwan. The unit of the survey was the household, that is, one person per household was interviewed. A total of 2243 persons were successfully interviewed. With a 95\% confidence interval, the sampling error was $\pm 2.07 \%$. We first employ a multinominal logistic analysis to investigate the probability that citizens would prefer a particular type of service channel to contact with the government. This study involves four types of service channels including telephone, in person, online, agents and others. In addition, two types of citizen engaging governmental services are examined: governmental service application (GSA) and knowing governmental information (KGI) ${ }^{2}$. The second level of analysis examines the use of e-voting system. We use logit maximum likelihood estimates to predict when a citizen will choose electronic voting system. Voting behavior is considered to be a dichotomous dependent variable and coded one if adopting E-voting and zero if not.

\section{$4 \quad$ Findings}

We first analyze what factors are associated with citizen preference of channel choices by three types of government services. Table 1 displays the multinominal logistic maximum likelihood estimates for different types of channels including telephone, in person, agents and others of GSA, with the online channel as the reference group ${ }^{3}$. The LR chi-square showed statistically significance, since it is less than .001, suggesting a good model fit.

\footnotetext{
2 Types of service channels are considered to be a nominal dependent variable. The dependent variable is coded as 0 for Online, 1 for telephone, 2 for in person, 3 for agents and others. The multinominal logistic analysis has a reference group as its category of Online channel $(0)$.

${ }^{3}$ Before utilizing multinominal logistic estimates, we employ LR tests to examine the combined alternatives. In the original questionnaire, five types of channel choices were provided including on-line, telephone, in person, agents, and others. The results found that there is no difference whether 'agents' and 'others' were combined or not. In order to simplify the model, we involve four types of channel choices including telephone, online, in person, and others. We then test the IIA assumption with the use of a Small-Hsiao test. The results indicate that the final model does not violate the IIA assumption.
} 
Table 1. Multinomial Logistic Model of Government Service Application (GSA)

\begin{tabular}{|c|c|c|c|c|}
\hline GSA model & $\begin{array}{l}\text { Tele- } \\
\text { phone/online }\end{array}$ & In Person/online & Others/online & Wald test \\
\hline & $\beta$ & $\beta$ & $\beta$ & $\beta$ \\
\hline Income & -.006 & .099 & $-.199 *$ & $11.59 *$ \\
\hline Age & $.019 *$ & $.030 * * *$ & $.034 * *$ & $15.97 * * *$ \\
\hline Education & $-.188 *$ & $-.329 * * *$ & $-.363 * *$ & $17.15^{* * *}$ \\
\hline Gender & -.185 & .160 & .361 & 5.26 \\
\hline ITUSE & .064 & .463 & .452 & 3.36 \\
\hline Risk concern & -.048 & -.035 & -.037 & .81 \\
\hline Privacy & -.035 & -.021 & -.043 & 1.43 \\
\hline Egov_trust & .077 & -.104 & .049 & 5.93 \\
\hline Political trust & $-.293 * * *$ & $-.311 * * *$ & $-.494 * * *$ & $24.18^{* * *}$ \\
\hline Internet trust & .082 & -.096 & -.080 & .85 \\
\hline $\begin{array}{l}\text { Contact with } \\
\text { gov }\end{array}$ & $.401 * * *$ & $.238 * *$ & -.165 & $18.01 * * *$ \\
\hline $\begin{array}{l}\text { Satisfaction } \\
\text { with egov info }\end{array}$ & $-449+$ & -.242 & -.173 & 3.60 \\
\hline $\begin{array}{l}\text { Dissatisfaction } \\
\text { with egov info }\end{array}$ & -.426 & -.039 & -.636 & 2.56 \\
\hline $\begin{array}{l}\text { Satisfaction } \\
\text { with egov } \\
\text { service }\end{array}$ & $-.606 * *$ & $-.712 * * *$ & -.060 & $15.76^{* * *}$ \\
\hline $\begin{array}{l}\text { Dissatisfaction } \\
\text { with egov } \\
\text { service }\end{array}$ & $-.1 .726^{* *}$ & $-1.730 * * *$ & -.055 & $17.81 * * *$ \\
\hline Intercept & 1.802 & 2.657 & 2.433 & \\
\hline $\mathrm{N}$ & 1008 & & & \\
\hline $\operatorname{LR~X}^{2}(45)$ & $204.41^{* * *}$ & & & \\
\hline PueudoR ${ }^{2}$ & .080 & & & \\
\hline \multicolumn{5}{|c|}{$\begin{array}{l}\text { Note: } \\
+\mathrm{p}<.1 ; * \mathrm{p}<.05 ; * * \mathrm{p}<.01 ;{ }^{* * *} \mathrm{p}<.001\end{array}$} \\
\hline
\end{tabular}


Table 2 presents the results of know government information (KGI) by three types of channels ${ }^{4}$.

Table 2. Multinomial logistic model of knowing Government Information (KGI)

\begin{tabular}{|c|c|c|c|}
\hline GSA model & Telephone/online & Others/online & Wald test \\
\hline & B & $\beta$ & $\beta$ \\
\hline Income & -.088 & -.113 & 3.871 \\
\hline Age & $.019 *$ & $.026 * * *$ & $\begin{array}{l}13.167 * * \\
*\end{array}$ \\
\hline Education & -.029 & $-.343 * * *$ & $\begin{array}{l}15.941^{* *} \\
*\end{array}$ \\
\hline Gender & $-.491 *$ & .149 & $7.245^{*}$ \\
\hline ITUSE & .493 & $.836 * * *$ & $10.591 * *$ \\
\hline Risk & -.019 & -.012 & .118 \\
\hline Privacy & .012 & .003 & .107 \\
\hline Egov_trust & .096 & .053 & 1.351 \\
\hline Political trust & -.097 & $-.365 * * *$ & $\begin{array}{l}19.949 * * \\
*\end{array}$ \\
\hline Internet trust & -.068 & -.342 & 2.949 \\
\hline Contact with gov & $.296 *$ & $.223^{*}$ & 8.398** \\
\hline $\begin{array}{l}\text { Satisfaction with egov } \\
\text { info }\end{array}$ & -.413 & -.501 & $6.240^{*}$ \\
\hline $\begin{array}{l}\text { Dissatisfaction with } \\
\text { egov info }\end{array}$ & -.232 & -.423 & 1.747 \\
\hline $\begin{array}{l}\text { Satisfaction with egov } \\
\text { service }\end{array}$ & -.346 & $-.562 *$ & $6.494 *$ \\
\hline $\begin{array}{l}\text { Dissatisfaction with } \\
\text { egov service }\end{array}$ & -.951 & -.706 & 3.458 \\
\hline
\end{tabular}

\footnotetext{
${ }^{4}$ Again, we use LR tests to detect the difference when alternatives are combined. The results discovered that three types of service channels can be combined together, including in person, agents, and others. We further examine Small-Hsiao test of IIA assumption with no violation. In order to simplify the model, the KGI model involves three types of service channels including telephone, online, and others.
} 


\begin{tabular}{lll}
\hline Intercept & -2.240 & .808 \\
$\mathrm{~N}$ & 1013 \\
$\operatorname{LR~X}^{2}(30)$ & $184.07 * * *$ \\
PueudoR & \\
Note: & .103 \\
$+\mathrm{p}<.1 ; * \mathrm{p}<.05 ; * * \mathrm{p}<.01 ; * * * \mathrm{p}<.001$.
\end{tabular}

In terms of what citizens prefer to use voting system, we use logistic regressions in our analysis. The logistic results are shown in Table 3.

Table 3. Logistic model of E-voting

\begin{tabular}{|c|c|c|c|}
\hline $\begin{array}{l}\text { Evoting model/ } \\
\text { variables }\end{array}$ & B & $\begin{array}{l}\text { Evoting model/ } \\
\text { variables }\end{array}$ & $\beta$ \\
\hline Income & .015 & Egov_trust & .012 \\
\hline Age & $-{ }_{-}^{-} .023 * *$ & Political trust & -.106 \\
\hline Education & $.200 * *$ & Internet trust & $.384 * *$ \\
\hline Gender & -.216 & Contact with gov & $-.180 *$ \\
\hline ITUSE & -.482 & $\begin{array}{l}\text { Satisfaction } \\
\text { egov info }\end{array}$ & .017 \\
\hline Risk & $-.095 *$ & $\begin{array}{l}\text { Dissatisfaction with } \\
\text { egov info }\end{array}$ & .162 \\
\hline \multirow[t]{2}{*}{ Privacy } & $.051 *$ & $\begin{array}{l}\text { Satisfaction } \\
\text { egov service }\end{array}$ & .121 \\
\hline & & $\begin{array}{l}\text { Dissatisfaction with } \\
\text { egov service }\end{array}$ & .054 \\
\hline Intercept & -.509 & $\operatorname{LR~X}^{2}(30)$ & $70.05 * * *$ \\
\hline $\mathrm{N}$ & 1022 & PueudoR $^{2}$ & .055 \\
\hline
\end{tabular}




\section{$5 \quad$ Discussion of Results}

On the basis of our data analysis, it reveals that trust is definitely significant for e-government adoption. This study indicates that the concept of trust plays different roles in different types of service functions. Our results discovered that political trust, but not trust in the Internet and egovernment, is significantly associated with channel choices in both GSA and KGI models. Political trust is the fundamental mechanism to underpin government legitimacy and the policy-making process. As citizens have higher level of political trust, they are more willing to pay taxes, follow the laws, engage in the public affairs and be in favor of new public policies. As a result, whether e-government can be citizens' preferable channel choice depends on the level of political trust.

Additionally, our findings suggest that higher level of trust in the Internet can increase citizens' willingness to adopt the electronic voting system. Trust in the Internet indicates an individual's perception of the digital surroundings that makes an environment safe. As ICTs becomes a popular and common phenomenon, people naturally feel comfortable in browsing government information and utilizing online applications. Yet, the design of e-voting systems requires complex technologies and knowledge, resulting in most people feeling unfamiliar and uncomfortable with the e-voting environment. As people feel distrust in the digital environment, they tend to favor voting in person or using traditional ways that they are most comfortable with. It would be difficult to undo the damage once citizens have decided not to adopt the e-voting system. Similarly, the level of risk perceptions can reduce citizens' willingness to use e-voting systems, because of the lack of control and the feelings of uncertainty associated with new technology.

In the examination of satisfaction with e-government services, the results illustrated, interestingly, that certain findings were opposite to what was predicted. Naturally, citizens who feel higher level of satisfaction with e-government services are more likely to choose online government application compared to the other traditional ones. However, citizens who are dissatisfied with e-government services, still have a high probability in choosing digital channels to complete government applications. Dissatisfaction with e-government services will not stop citizens from adopting digital channels. The findings imply that citizens would rather employ online service applications instead of other traditional ones, once they have begun using it. In other words, citizens will 
continue using e-service delivery once they have used it for the first time. As a result, governments need to make an effort to promote egovernment and encourage citizens to use it in order to change their behavior pattern.

\section{Conclusion}

This study investigated the role of trust in e-governance, by comparing e-government to traditional service delivery channels, using data collected across Taiwan. Our results indicated that different service functions of e-government can be influenced by different types of trust. This study discovered that the assessment of e-government functions needs to be differentiated from the traditional models. E-government has many different functions offering a variety of public services such as information, online application, and electronic participation. Few empirical studies have been conducted to examine citizens' preference toward service channels by the diversity of government services. This study proposed and tested a multinominal logit and logistic model to explain the concept of trust by different types of government services.

In addition, this exploratory study contributes to the trust in egovernment literature by uncovering the dimensions of trust's role in influencing channel choices. Our findings highlight the fact that the role of trust unfolds different angles in the e-government services. Contrary to our expectations, trust in Internet and trust in e-government were not significant. Political trust, on the other hand, in both functions of public services (KGI and GSA), wielded great influence on the usage of e-government. As in the electronic voting system, the trust in Internet becomes prominent in its ability to affect citizens' willingness to use new technology.

The results indicated that e-government is worth pursuing as a means of service delivery channel, whether citizens are satisfied or dissatisfied with e-government service. Interaction through online transactions, applications or question services could be especially important for increasing e-government utilization.

\section{References}

1. Abdelghaffar, H.: Citizens' Readiness for E-Government in Developing Countries (CREG). In: S. Kamel (Ed.) E-Strategies for Technological Diffusion and Ddoption: 
National ICT Approaches for Socioeconomic Development, pp. 215-233. Hershey, PA: IGI Global (2010)

2. Alsaghier, H., Ford, M., Nguyen, A., \& Hexel, R.: Conceptualising Citizen's Trust in Egovernment: Application of Q Methodology. Electronic Journal of E-Government, 7(4), 295-310 (2009)

3. Anderson, Rolph E., \& Srinivasan, Srini S.: E-Satisfaction and E-Loyalty: A Contingency Framework. Psychology \& Marketing, 20(2), 123-138 (2003)

4. Bélanger, France, \& Carter, Lemuria.: Trust and Risk in E-Government Adoption. The Journal of Strategic Information Systems, 17(2), 165-176 (2008)

5. Carter, Lemuria, \& Bélanger, France.: The Utilization of E-Government Services: Citizen Trust, Innovation and Acceptance Factors. Information Systems Journal, 15(1), 5-25 (2005)

6. Carter, Lemuria, \& Weerakkody, Vishanth.: E-Government Adoption: A Cultural Comparison. Information Systems Frontiers, 10(4), 473-482 (2008)

7. Dawes, Sharon S.: The Evolution and Continuing Challenges of E-Governance. Public Administration Review, 68(s1), 86-102 (2008)

8. DeLone, William H., \& McLean, Ephraim R.: Measuring E-Commerce Success: Applying the DeLone \& McLean Information Systems Success Model. International Journal of Electronic Commerce, 9(1), 31-47 (2004)

9. Ebbers, W. E., Pieterson, W. J., \& Noordman, H. N.: Electronic Government: Rethinking Channel Management Strategies. Government Information Quarterly, 25(2), 181-201 (2008)

10. Horst, Mark, Kuttschreuter, Margôt, \& Gutteling, Jan M.: Perceived Usefulness, Personal Experiences, Risk Perception and Trust as Determinants of Adoption of E-Government Services in The Netherlands. Computers in Human Behavior, 23(4), 1838-1852 (2007)

11. Morgeson Iii, Forrest V., VanAmburg, David, \& Mithas, Sunil.: Misplaced Trust? Exploring the Structure of the E-Government-Citizen Trust Relationship. Journal of Public Administration Research \& Theory, 21(2), 257-283 (2011)

12. Parent, Michael, Vandebeek, Christine A., \& Gemino, Andrew C.: Building Citizen Trust Through E-Government. Government Information Quarterly, 22(4), 720-736 (2005).

13. Pieterson, Willem, Ebbers, Wolfgang, \& van Dijk, Jan.: Personalization in the Public Sector: An Inventory of Organizational and User Obstacles towards Personalization of Electronic Services in the Public Sector. Government Information Quarterly, 24(1), 148164 (2007)

14. Pieterson, Willem, \& van Deursen, A.: The Internet as a Service Channel in the Public Sector. Paper presented at the ICA, Dresden Germany (2006)

15. Reddick, Christopher G.: Citizen Interaction with E-Government: From the Streets to Servers? Government Information Quarterly, 22(1), 38-57 (2005)

16. Reddick, Christopher G., \& Turner, M.: Channel Choice and Public Service Delivery in Canada: Comparing E-Government to Traditional Service Delivery. Government Information Quarterly, 29(1), 1-11 (2012)

17. Teo, Thompson S. H. , Srivastava, Shirish C., \& Jiang, Li.: Trust and Electronic Government Success: An Empirical Study. Journal of Management Information Systems, 25(3), 99-131 (2008)

18. Thomas, John Clayton, \& Streib, G.: The New face of Government: Citizen-Initiated Contacts in the Era of E-Government. Journal of Public Administration Research and Theory, 13(1), 83-102 (2003) 
19. Warkentin, Merrill, Gefen, David, Pavlou, Paul A., \& Rose, Gregory M.: Encouraging Citizen Adoption of E-Government by Building Trust. Electronical Markets, 12(3), 157162 (2002)

20. Welch, Eric W., Hinnant, Charles C., \& Moon, M. Jae.: Linking Citizen Satisfaction with E-Government and Trust in Government. Journal of Public Administration Research and Theory, 15(3), 371-391 (2005) 